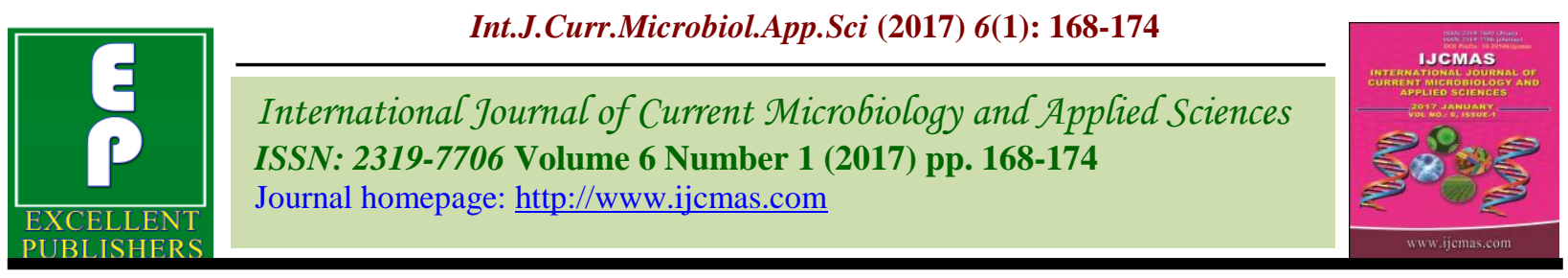

Original Research Article

http://dx.doi.org/10.20546/ijcmas.2017.601.021

\title{
Evaluation of Screening Tests to Detect Asymptomatic Bacteriuria in Antenatal Women
}

\author{
K.V. Leela*, Thyagarajan Ravinder, S. Hemalatha, P. Prabha and K. Chandrasekaran \\ Department of Microbiology, Govt. Kilpauk, Medical College and Hospital, \\ Chennai- 600010, India \\ *Corresponding author
}

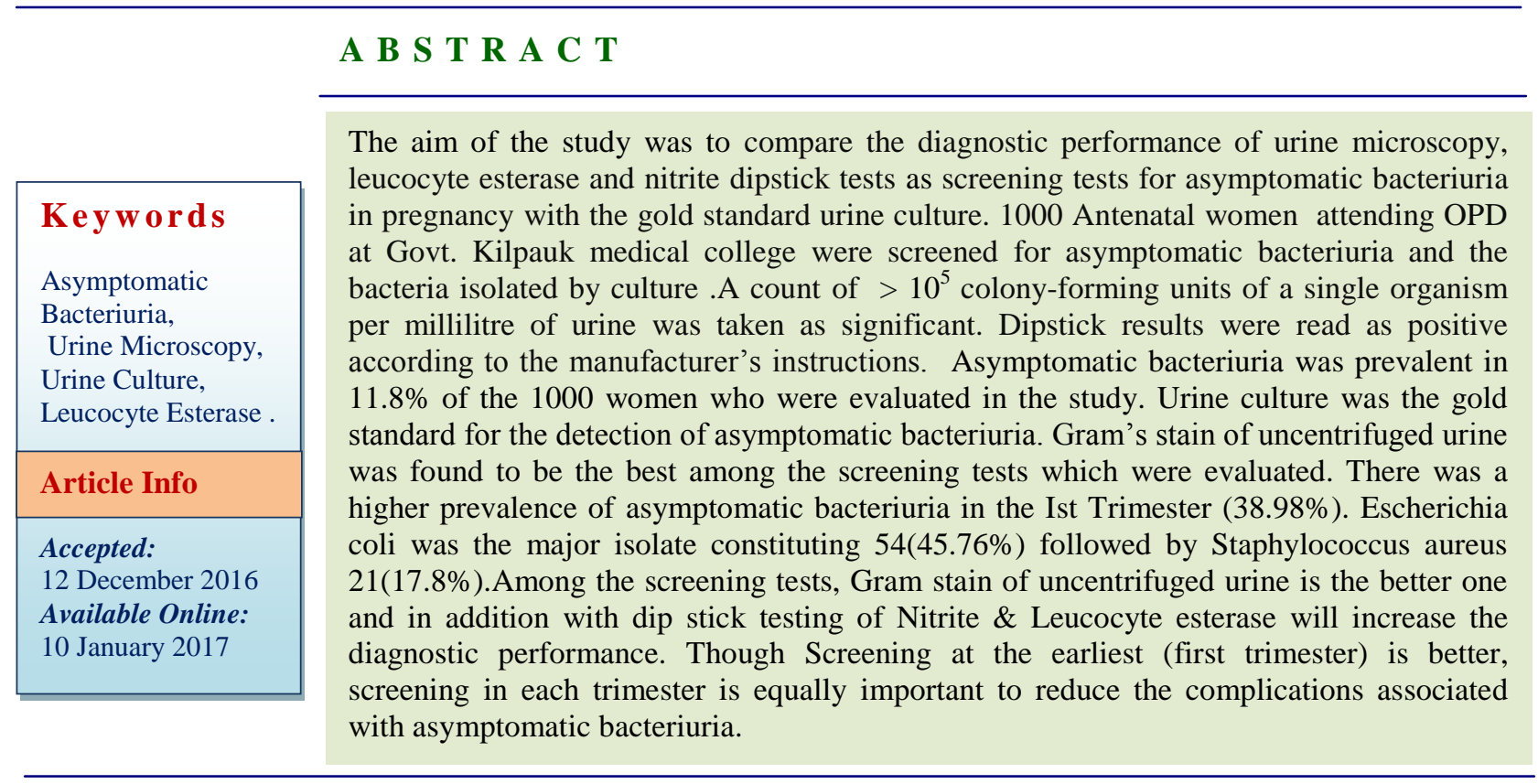

\section{Introduction}

Urinary tract infection is mainly a disease of the females, due to the anatomical structure of the female urethra (Shruthi et al., 2012; Lavanya et al., 2002). There are 2 types of urinary tract infection (UTI). They are asymptomatic and symptomatic urinary tract infection (Sujatha et al., 2004; Jeyaseelan et al., 2013; Annie et al., 2014). The definition of asymptomatic bacteriuria is the occurrence of actively multiplying bacteria, more than $10^{5}$ bacteria per $\mathrm{ml}$ of urine inside the urinary tract, exclusive of the distal urethra at a time when the patient has nil symptoms of UTI
(Santogita et al., 2013; Chandel et al., 2012). In pregnancy, urinary tract infections commonly occur, because of the physiological and morphological changes that occur in the genitourinary tract. In pregnant women, the occurence of asymptomatic bacteriuria was found to be $2 \%$ to $10 \%$. The relatively increased occurence of asymptomatic bacteriuria, the consequences faced by the antenatal women, the ability to avoid undesirable outcomes with the management justifies the testing of asymptomatic bacteriuria in pregnancy. Both 
screening and treatment of all pregnant women for asymptomatic bacteriuria are therefore recommended.

The gold standard test for detection of bacteriuria is urine culture, but it takes 24 48 hours to obtain results (Titoria et al., 2014). To overcome this problem, many alternative screening methods have been evaluated, including urine microscopy, chemical analysis using a dipstick method, Gram staining, dipslide urine culture and bioluminescence. Each method has advantages and disadvantages in terms of capital investment, running costs, automation, convenience and adaptability for use in the ward or clinic. The Griess nitrite test relies on the fact that the enteric Gram-negative bacilli and some Gram-positive cocci reduce nitrate present in urine to nitrite. The leucocyte esterase test is a colorimetric test that detects specific byproducts of leucocytes in the urine.Urine reagent dipstick testing is rapid, inexpensive and requires little technical expertise.

This study was aimed at comparing the diagnostic performance of urine microscopy and reagent strip tests with urine culture as standard for detecting asymptomatic bacteriuria in antenatal women.

The main aim of this study to compare the efficacy of screening tests with urine culture to detect asymptomatic bacteriuria in antenatal women.

\section{Materials and Methods}

This study was done from January 2014 to June 2015 at Government Kilpauk Medical College and Hospital, Chennai to compare the efficacy of screening tests to detect asymptomatic bacteriuria in pregnancy. Totally 1000 urine samples were collected from 18-40 years of age group among pregnant women and were studied during this period.

\section{Sample Collection}

Mid stream urine specimens were collected in a wide mouthed sterile container from the antenatal women who attended antenatal clinic at Government Kilpauk Medical College and Hospital were included in the study after obtaining informed consent. Specimens were transported immediately to the microbiology laboratory and processed without delay.

Sample Processing (Kheya et al., 2014; Cheesbrough, 2014)

\section{Macroscopic examination}

Colour, turbidity and deposits of the urine samples were observed macroscopically and the results were recorded (Cheesbrough, 2014).

\section{Screening Tests}

One half of collected urine was taken for urine microscopy and culture and the other half was used for commercial reagent strip test for the nitrite and leucocyte esterase.

\section{Leukocyte Esterase Test and Nitrite Test (Gayathree et al., 2010)}

Evidence of a host response to infection is the presence of PMN, polymorphonuclear leucocytes in the urine. Because inflammatory cells produce Leukocyte esterase, a simple and rapid method that measures this enzyme has been developed. The nitrate reductase test is a screening procedure that looks for the presence of urinary nitrite, an indicator of UTI. Nitrate reducing enzymes that are produced by the most common urinary tract pathogens reduce nitrate to nitrite. Uncentrifuged urine specimens were used for the presence of nitrite and leukocyte esterase activity. The 
presence of nitrite and leucocyte esterase is noted by specific colour change in the panel provided by the manufacturer. The samples were tested as per the manufacturer's instructions. The results were compared with the colour code on the reagent strip container between 30 and 60 seconds as per the instruction manual. The positive results were recorded (Douglas, 1998).

\section{Microscopic examination}

Pus cell count of the uncentrifuged urine (Titoria et al., 2014)

Presence of polymorphonuclear neutrophils (PMNs) was detected by urine wet mount examination. Microscopic analysis was done with $0.05 \mathrm{ml}$ of the uncentrifuged urine.

$\geq 5$ pus cells / high power field - positive finding.

\section{Gram's Staining of Uncentrifuged Urine}

A loopful of uncentrifuged, well mixed urine was placed on a grease free slide and it was air dried. Then, the smear was stained by Gram's stain and was observed under oil immersion. The presence of 1 bacteria / Oil immersion field in 20 fields correlated with the diagnosis of significant bacteriuria of $10^{5}$ $\mathrm{CFU} / \mathrm{ml}$ of urine ${ }^{13}$

\section{Urine culture}

Semi-quantitative method (Titoria et al., 2014; Collee et al., 1996; Sushama et al., 2012)

To isolate the organism, a semi-quantitative calibrated loop technique was used. One loopful of properly mixed urine that was not centrifuged was inoculated onto the surface of Nutrient agar, 5\% sheep Blood agar, Mac Conkey agar and Cysteine Lactose
Electrolyte Deficient agar using a calibrated loop that delivers $0.01 \mathrm{ml}$ of urine sample. The culture plates were incubated under aerobic conditions at $37^{\circ} \mathrm{C}$ for $18-24$ hours. The colonies were counted using colony counter and the number of colony forming units were multiplied by 100 to find out the number of microorganisms present per millilitre of urine.

$\geq 10^{5}$ colony forming units / $\mathrm{ml}$ significant bacteriuria.

The diagnostic criteria for asymptomatic bacteriuria was considered when atleast two consecutive urine samples showed more than or equal to $10^{5}$ colony forming units in $1 \mathrm{ml}$ of urine of the single species without any UTI symptoms (Lindsay, 2003). To differentiate pathogens from commensals, standard microbiological methods were followed. The importance of the isolates were identified based on presence of pus cells in direct gram staining, pure growth and colony morphology on culture plates and biochemical reactions by using standard microbiological techniques.

\section{Results and Discussion}

Antenatal women attending Obstetrics OP at Government Kilpauk Medical College and Hospital, Chennai were included in the study for asymptomatic bacteriuria detection. The observations were recorded and analysed. The results were as follows:

Out of the 118 isolates isolated from 1000 antenatal women, Escherichia coli $54(45.76 \%)$ was the predominant isolate followed by Staphylococcus aureus 21(17.8\%). Proteus mirabilis was the least common organism isolated $2(1.69 \%)$.

The culture positives with asymptomatic bacteriuria in pregnancy were $11.8 \%$. The culture positives were more in the $21-30$ 
years age group, primigravida and in the first trimester. Gram negative bacilli were the predominant bacteria $78(66.10 \%)$, isolated in women with asymptomatic bacteriuria in antenatal women. This study aims at comparison of efficacy of screening tests with the urine culture to detect asymptomatic bacteriuria in pregnancy. The study was conducted from January 2014 to June 2015, among 1000 antenatal women from 18 to 40 years of age without any symptoms of urinary tract infection. The observations were recorded, analysed and discussed as follows.

In this study, number of culture positive urine samples was $118(11.8 \%)$. The culture positives were more in the 21-30 years age group $78(66.10 \%)$, primigravida $58(49.2 \%)$ and in the first trimester $46(38.98 \%)$. Gram negative bacilli were the predominant bacteria 78(66.10\%) isolated in women with asymptomatic bacteriuria. Escherichia coli was the major isolate constituting $54(45.76 \%)$ followed by Staphylococcus aureus $21(17.8 \%)$

Pus cells were present in 67(56.7\%) by wet mount method. Direct Gram stain smear positive for organisms were 93(78.81\%). Leukocyte esterase test was positive in $71(60.16 \%)$ and Nitrite test was positive in $89(75.4 \%)$ by dipstick method.

Urine culture was taken as the gold standard, against which the comparison of various screening tests were done. Statistical formulas were applied and thus sensitivity, specificity, positive predictive value (PPV), negative predictive value (NPV) and diagnostic accuracy were calculated.

In our evaluation of the screening tests like Gram's stain of uncentrifuged urine, the Leukocyte esterase test and the Nitrite test, we found Gram's stain of uncentrifuged urine to have a good sensitivity (78.81\%), specificity (98.98\%), positive predictive value $(91.18 \%)$ and negative predictive value (97.22\%) with a good diagnostic accuracy value of $96.61 \%$ than other screening tests vis-a -vis urine culture . Though the Leucocyte Esterase alone showed a good specificity (98.98\%), it was less sensitive $(60.17 \%)$ than Gram's stain (78.81\%). The nitrite tests has comparative sensitivity $(75.42 \%)$ and positive predictive value $(89 \%)$ with that of Gram's stain of uncentrifuged urine, but have low specificity $(88.78 \%)$ and negative predictive value $(75 \%)$. Combined Leukocyte esterase and Nitrite tests show a good sensitivity and specificity that of Gram's stain of uncentrifuged urine.

Among the screening tests evaluated, we observed that Gram's stain of uncentrifuged urine was the best screening method for Asymptomatic bacteriuria, as in other studies. The Dipstick test for Leukocyte esterase and Nitrites can also serve as a rapid screening method for asymptomatic bacteriuria, as its sensitivity and specificity is nearer to that of Gram's stain and the urine culture.

Table.1 Asymptomatic bacteriuria in antenatal women $(n=1000)$

\begin{tabular}{|l|l|}
\hline \multicolumn{2}{|c|}{ Asymptomatic Bacteriuria In Antenatal Women } \\
\hline Total number of Antenatal women & $\begin{array}{l}\text { Antenatal women with Asymptomatic } \\
\text { bacteriuria }\end{array}$ \\
\hline 1000 & $118(11.80 \%)$ \\
\hline
\end{tabular}

Out of the 1000 urine samples, $118(11.8 \%)$ were culture positive. 
Table.2 Relationship of Parity and culture positives ( $\mathrm{n}=118)$

\begin{tabular}{|l|l|}
\hline Gravida & Culture Positives \\
\hline Primi gravida & $58(49.2 \%)$ \\
\hline Second gravida & $41(34.7 \%)$ \\
\hline Third gravida & $18(15.3 \%)$ \\
\hline Gravida more than three & $1(0.8 \%)$ \\
\hline Total & $118(100 \%)$ \\
\hline
\end{tabular}

Out of 118 bacterial isolates, the culture positives were more in the Primigravida 58(49.2\%).

Table.3 Relationship of duration of pregnancy and culture positives $(\mathrm{n}=118)$

\begin{tabular}{|l|l|}
\hline Trimester & Culture positives \\
\hline I & $46(38.98 \%)$ \\
\hline II & $40(33.89 \%)$ \\
\hline III & $32(27.11 \%)$ \\
\hline Total & $118(11.8 \%)$ \\
\hline
\end{tabular}

Out of the 118 bacterial isolates the culture positives were more in the first Trimester $46(38.98 \%)$

Table.4 Screening tests for asymptomatic bacteriuria in pregnancy $(\mathrm{n}=1000)$

\begin{tabular}{|c|c|c|c|c|c|c|c|c|}
\hline & \multicolumn{2}{|c|}{ Pus cells } & \multicolumn{2}{|c|}{$\begin{array}{c}\text { Direct gram stain } \\
\text { smear }\end{array}$} & \multicolumn{2}{|c|}{ Nitrate reduction } & \multicolumn{2}{|c|}{ Leucocyte esterase } \\
\hline $\begin{array}{l}\text { Culture } \\
\text { Positivity }\end{array}$ & Positive & Negative & Positive & Negative & Reduced & $\begin{array}{c}\text { Not } \\
\text { Reduced }\end{array}$ & Positive & Negative \\
\hline $\begin{array}{l}\text { Culture } \\
\text { Positive }\end{array}$ & 67 & 51 & 93 & 25 & 89 & 29 & 71 & 47 \\
\hline $\begin{array}{l}\text { Culture } \\
\text { Negative }\end{array}$ & 30 & 852 & 9 & 873 & 11 & 871 & 36 & 846 \\
\hline Sensitivity\% & \multicolumn{2}{|c|}{56.78} & \multicolumn{2}{|c|}{78.81} & \multicolumn{2}{|c|}{75.42} & \multicolumn{2}{|c|}{60.17} \\
\hline Specificity\% & \multirow{2}{*}{\multicolumn{2}{|c|}{96.6}} & \multirow{2}{*}{\multicolumn{2}{|c|}{$\frac{98.98}{9118}$}} & \multicolumn{2}{|c|}{88.78} & \multicolumn{2}{|c|}{98.98} \\
\hline PPV\% & & & & & 8 & & & \\
\hline NPV\% & \multicolumn{2}{|c|}{$\begin{array}{l}69.01 \\
94.35\end{array}$} & \multicolumn{2}{|c|}{97.22} & \multicolumn{2}{|c|}{75} & \multicolumn{2}{|c|}{94.74} \\
\hline $\begin{array}{l}\text { Diagnostic } \\
\text { Accuracy\% }\end{array}$ & \multicolumn{2}{|c|}{91.39} & \multicolumn{2}{|c|}{96.61} & \multicolumn{2}{|c|}{81.48} & \multicolumn{2}{|c|}{91.7} \\
\hline
\end{tabular}

Out of the 118 culture positives, 67 had significant pus cells, 93 had organisms in Gram stain, 89 reduced nitrate and 71 were positive for leucocyte esterase by urine dipstick. 
Table.5 Distribution of organisms $(n=118)$

\begin{tabular}{|l|l|}
\hline Organisms & Percentage \\
\hline Escherichia coli & $54(45.76 \%)$ \\
\hline Staphylococcus aureus & $21(17.80 \%)$ \\
\hline Klebsiella pneumoniae & $19(16.10 \%)$ \\
\hline Staphylococcus saprophyticus & $10(8.45 \%)$ \\
\hline Enterococcus faecalis & $9(7.63 \%)$ \\
\hline Pseudomonas aeruginosa & $3(2.54 \%)$ \\
\hline Proteus mirabilis & $2(1.69 \%)$ \\
\hline
\end{tabular}

In conclusion, asymptomatic bacteriuria was prevalent in $11.8 \%$ of the 1000 women who were evaluated in the study with Escherichia coli as the major isolate constituting $54(45.76 \%)$ followed by Staphylococcus aureus 21(17.8\%). Urine culture remained the gold standard for the detection of asymptomatic bacteriuria. Gram's stain of uncentrifuged urine with diagnostic accuracy value of $96.61 \%$ was observed to be the best among the screening tests which were evaluated. Addition of combined dipstick testing (Nitrite and Leucocyte esterase) with urine microscopy will improve further its diagnostic performance.

Screening at the earliest may reduce the sequelae of asymptomatic bacteriuria during pregnancy preferably in the first trimester by intiating antimicrobial treatment early in pregnancy. Screening is also important in all three trimesters to prevent the dangerous complications associated with asymptomatic bacteriuria during rest of the pregnancy. The present study showed high occurrence of asymptomatic bacteriuria in pregnant women which if not treated, might lead to various maternal and neonatal complications. Hence, screening and management of asymptomatic bacteriuria need to be incorporated as a routine antenatal care for an integrated approach to safe motherhood and newborn health.

\section{References}

Annie Rajaratnam, Neha Maria Baby, Thomas. S. Kuruvilla, Santhosh Machado. 2014. Diagnosis of asymptomatic bacteriuria and associated risk factors among pregnant women in Mangalore, Karnataka, India. J. Clin. Diagn. Res., 8(9): OC23-OC25.

Aziz marjan khattak, Habbibullah khan, Wasim Akhtar, Ihsanullah Mahsud, Bushra. 2004. Accuracy of Griess nitrite test to predict Asymptomatic bacteriuria during pregnancy. Gomal J. Med. Sci., 2(1): 20-23.

Chandel Lata, R., Kanga Anil, Thakur Kamlesh, Mokta Kiran, K., Sood Anuradha, et al. 2012. Prevalence of pregnancy associated asymptomatic bacteriuria: Astudy done in a Tertiary care hospital. The J. Obstetrics and Gynecol. India, 62(5):511-514.

Cheesbrough, M. Examination of urine. District Laboratory Practice in Tropical countries. Part 2, Chapter 7.12, page 105115.

Collee, J.G., Miles, R.S., Watt, B. 1996. Urinary tract infections. Mackie and McCartney practical medical microbiology. 14th edition. Churchill Livingstone, New York, page 84-90.

Douglas, G., Tincello. 1998. Evaluation of reagent strips in detecting asymptomatic bacteriuria in early pregnancy. British Med. J., 316:435. 
Gayathree, L., Shetty, S., Deshpande, S.R., Venkatesha, D.T. 2010. Screening for Asymptomatic bacteriuria in pregnancy: an evaluation of various screening tests at the hassan district hospital, india. J. Clin. Diag. Res., (serial online) 2010 August (cited: 2010 August 15 ); 4:2702-2706.

Jeyaseelan Senthinath, T., P. Chitra Rajalakshmi, R. Keerthana, R.S. Vigneshwari, P. Revathi et al. 2013. Prevalence of asymptomatic bacteriuria among antenatal women in rural tertiary care hospital, Tamilnadu, India. Int. J. Curr. Microbiol. App. Sci., 2(1): 80-85.

Kheya Mukherjee, Saroj Golia, Vasundha C.L., Babita, Debojyoti Bhattacharjee et al. 2014. A study on asymptomatic bacteriuria in pregnancy: prevalence, etiology and comparision of screening methods. Int. J. Res. Med. Sci., 2(3): 1085-1091.

Lavanya, S.V., D. Jogalakshmi. 2002. Asymptomatic bacteriuria in antenatal women. Indian J. Med. Microbiol., 20(2): 105-106.

Lindsay, E., Nicolle. 2003. Asymptomatic bacteriuria When to screen and when to treat. Infect. Dis. Clin. N. Am., 17: 367394.

Rajshekhar, D., Kerure, Umashanker. 2013. Prevalence of Asymptomatic bacteriuria among pregnant women in a tertiary care hospital. Int. J. Scientific And Res., 3(11): 1-4.

Santogita Jain, Jaydev Pandya, Sanjay Mehta, Anil Jain, Kunjan Kikani et al. 2013. Evaluation of asymptomatic bacteriuria in antenatal women at $\mathrm{Cu}$ Shah Medical College and Hospital, Surendranagar, Gujarat. Int. J. Med. Sci. Public Health,
2(4):1021-1023.

Shruthi, N., Ravikumar, Ravish kumar. 2012. Phenotypic study of virulence factors in Escherichia coli isolated from Antenatal cases, catheterised patients, and faecal flora. J. Clin. Diagn Res., 6(10):16991703.

Sudha Birader Kerure, Rajeswari Surpur, Sheela, S. Sagarad, Sneha Hegadi. 2013. Asymptomatic bacteriuria among pregnant women. International Journal of Reproduction, Contraception, Obstetrics and Gynecol., 2(2): 213-216.

Sujatha, R., Manju nawani. 2014. Prevalence of asymptomatic bacteriuria and its antibacterial susceptibility pattern among pregnant women attending the antenatal clinic at Kanpur, India. J. Clin. Diagn. Res., 8(4): DC01-DC03.

Sushama, S., Thakre, Supriya, S., Dhakne, Subash, B., Thakre, Amol, D., Thakre, Suresh, M., Ughade. et al. 2012. Can the Griess Nitrite test and a Urinary pus cell count of $\geq 5$ cells per micro litre of urine in pregnant women be used for the screening or the early detection of urinary tract infections in rural India? $J$. Clin. Diagn. Res., 6(9): 1518-1522.

Titoria, A., A. Gupta, A.M. Rathore, S.K. Prakash, D. Rawat, U. Manaktala. 2014. Asymptomatic bacteriuria in women attending an antenatal Clinic at a tertiary care centre. S. Afr. J. OG., 20(1): 4-7. DOI:10.7196/SAJOG.733

Titoria, A., A.M. Rathore, A. Gupta, S.K. Prakash, D. Rawat. et al. 2014. Asymptomatic bacteriuria in women attending an antenatal clinic at a tertiary care centre. S. Afr. J. OG., 20(1): 4-7.

\section{How to cite this article:}

Leela, K.V., Thyagarajan Ravinder, S. Hemalatha, P. Prabha and Chandrasekaran, K. 2016. Evaluation of Screening Tests to Detect Asymptomatic Bacteriuria in Antenatal Women. Int.J.Curr.Microbiol.App.Sci. 6(1): 168-174. doi: http://dx.doi.org/10.20546/ijcmas.2017.601.021 